Revue d'histoire de l'Amérique française

ZRS REVUE D.HISTOIRE DE L'AMÉRIQUE FRANÇAISE

\title{
La querelle des prisons (Bas-Canada, 1805-1807) (suite et fin)
}

\section{Jean-Pierre Wallot}

Volume 14, numéro 4, mars 1961

URI : https://id.erudit.org/iderudit/302081ar

DOI : https://doi.org/10.7202/302081ar

Aller au sommaire du numéro

Éditeur(s)

Institut d'histoire de l'Amérique française

ISSN

0035-2357 (imprimé)

1492-1383 (numérique)

Découvrir la revue

Citer cet article

Wallot, J.-P. (1961). La querelle des prisons (Bas-Canada, 1805-1807) (suite et fin). Revue d'histoire de l'Amérique française, 14(4), 559-582.

https://doi.org/10.7202/302081ar d'utilisation que vous pouvez consulter en ligne.

https://apropos.erudit.org/fr/usagers/politique-dutilisation/ 


\section{LA QUERELLE DES PRISONS (BAS-CANADA, 1805-1807) * \\ (suite et fin)}

\section{Chapitre VII}

\section{LA Guerre de Plumes}

Controverse passionnée entre Le Canadien et le Mercury - Le Canadien revendique l'application de la constitution de 1791 - Le Mercury expose des vues anglicisatrices et impérialistes - Opinion d'un anglais modéré - Le Mercury voudrait qu'on enlève tout privilège aux Canadiens français - Distinction du Canadien entre les «bons » et les «mauvais》 Anglais - Opposition du Canadien à l'immigration britannique et américaine - L'esprit colonisateur anime le Mercury - Le Canadien parle de ministère - Un correspondant du Mercury prévoit la grande expansion du Canada anglais - Quelques blagues échangées entre les deux journaux.

Après les individus et les partis, les journaux entreprirent de se colleter eux aussi. Une vive controverse s'engagea entre Le Canadien et le Quebec Mercury. De semaine en semaine, leurs rédacteurs croisaient le fer, s'estocadaient, se donnaient la réplique ou portaient de nouveaux coups. Ils ferraillaient, tantôt sur le plan constitutionnel, tantôt sur le plan des personnalités, souvent sur les deux et toujours à grand renfort de sarcasmes et d'ironie. Dans cette guerre de plumes, il y eut des excès de part et d'autre. Mais en général, les articles découpent bien les arêtes de la pensée de chaque groupe ethnique. Et ainsi les journaux portèrent la querelle devant le grand public.

De part et d'autre, il y eut donc des personnalités. Cependant, la discussion des doctrines politiques occupa une large

* Voir notre Revue, XIV: 61-86, 259-276, 395-407. 
part des débats. Les rédacteurs du Canadien, Bédard en particulier, cherchaient à se maintenir sur le terrain constitutionnel afin de rehausser la force de leurs revendications et d'édifier une doctrine plus cohérente. Ils rappelaient souvent les principes qui guidaient le parlement britannique. Se basant sur la constitution de 1791, sur les principes de la constitution anglaise et sur l'autorité du parlement impérial, ils avaient beau jeu pour réclamer en faveur des Canadiens l'influence à laquelle ils croyaient avoir droit. L'Angleterre n'avait pas lésiné sur les concessions et leur avait donné une constitution libérale et avantageuse. Qu'on en applique les principes, disaient-ils. En pratique, c'était demander une autorité de plus en plus étendue par la législature coloniale.

Le Quebec Mercury conteste les droits de la majorité de la Chambre et la constitutionnalité de ses actions. Il tente d'établir l'incompatibilité quasi-congénitale entre des descendants de Français, et l'amour de la liberté et des institutions britanniques. Ses rédacteurs insistent sur l'avenir anglais du Canada qui, disentils, deviendra un grand tout britannique grâce à la colonisation et à l'empire. Or les Canadiens français barrent la route et ne veulent pas $d$ '《étrangers ». Il s'agit donc de les en déloger.

Le Mercury du 24 novembre 1806 fit paraître une réponse à une lettre adressée à son éditeur par un anglais modéré qui désavouait des expressions d'opinion comme celles que nous avons décortiquées au chapitre précédent. Le Canadien traduisit et publia cette lettre. L'auteur qui signe «Anglo-Canadiensis», admet qu'il faut s'opposer « au débordement du torrent de l'ambition française ». Mais, dit-il, pourquoi défranciser les Canadiens qui ne sont plus des Français; mieux vaudrait suivre la politique qu'avait autrefois pratiquée Rome vis-à-vis des Grecs et des autres peuples conquis. Pourquoi ne pas leur laisser leur langue et leurs coutumes? Les Canadiens s'en montreraient reconnaissants :

... Un Canadien ne peut-il pas être, et n'est-il pas réellement Anglais par son amour pour la liberté Anglaise, son attachement au Gouvernement Anglais, et son aversion aux principes Français ? La 
loyauté consiste-t-elle dans la similitude du langage ? Si cela n'est pas, et si elle ne peut se trouver que dans la similitude des principes, pourquoi défranciser le Canada? Dans quel point essentiel, les sujets Canadiens diffèrent-ils des sujets Anglais? Si une telle différence existe, pourquoi donc les Américains, dont le langage, la religion et les manières étaient celles des Anglais, se sont-ils soustraits à leur obéissance, et ont-ils appelé les Français à leur secours ?

... Ne serait-il pas plus à propos d'élever un rempart... contre les intrigues de nos voisins, plutôt que de faciliter la communication avec eux, en répandant leur langage ? Car si suivant son raisonnement la langue anglaise est un rempart contre l'ambition Française, pourquoi la langue Française n'en seraitelle pas un contre les spéculations Américaines ? ${ }^{1}$

L'auteur ne semble pas saisir très bien le fond du problème qui est la lutte entre deux races pour la domination du Bas-Canada.

«Anglicanus » répliqua dans le Mercury:

Can a french descendant love english liberty, be attached to english government, and have an aversion to french principles, without unfrenchifying himself to a certain extent ? It is impossible. The great ambition of a frenchman is to be led by the nose in pursuit of some splendid meteor ...2

\section{Pourquoi défranciser le Canada?}

Why the policy is to annul the just claim of the french to an alliance from the Canadians.

.....The Greeks refined the Romans [but] the great cause of the dissemination of urbanity through the earth, is commerce, by the intercourse it occasions among different nations and their consequent knowledge of each other.

Anglo-Canadiensis is not more happy in his citation of the cases of Guernsey and Jersey than in that of Rome. These two islands were much too small and well peopled, to admit of colonisation ..... What analogy is there between these two small islands,

1 Le Canadien, 29 novembre 1806.

2 Quebec Mercury, 24 novembre 1806. 
admitting of no colonization, and Canada, which, at the time of its conquest by the English, contained only about 45,000 souls, to cover millions of acres of land, but which circumscribed population, is at this day, greatly augmented by a numerous english colonization ...... When France would frenchify the universe, it is the business of England to endeavour to anglify it .....

..... There can be no kind of doubt of the great benefit of a similarity of manners and language between people connected by commercial relations, which in some cases, particularly in that of Great Britain with the United States, ... may be a far better relationship than a political one. The political separation was the result of a difference of opinion on a constitutional question. If it be admitted that the situation of a Canadian is ameliorated by his becoming english to a certain extent; his welfare must augment in the proportion of his progress to the completion of that character. ${ }^{3}$

«Anglicanus » représente ici l'opinion de tous ceux qui croient en la colonisation anglaise et en l'assimilation des Canadiens.

Dans ce même numéro du Mercury, un autre correspondant qui écrit sous le pseudonyme d' «Akritomuthos », pousse beaucoup plus loin: il réclame qu'on enlève tout privilège aux Canadiens français: «I do not apprehend that a french paper, properly conducted, would be so very productive of bad effects; but to encourage the present such as it is, would be highly improper and impolitic ..... What remains to do ? To retrench the priviledges which are called few, but in fact too many, enjoyed too freely by the conquered; and have the public administration of affairs carried on solely in english, by englishmen, or men english in principle. » 4 C'est vraiment de la haine qui anime «Akritomuthos ».

Le Canadien ne tire pas de l'arrière et n'ânonne pas dans cette lutte. Dans l'édition du 29 novembre, un correspondant qui signe «Caius», établit une distinction entre les Anglais. Il cite

3 Quebec Mercury, 24 novembre 1806.

4 Quebec Mercury, 24 novembre 1806. 
d'abord une lettre de Murray aux Lords du Commerce: l'ancien gouverneur y condamnait les Anglais du Canada qui auraient constitué «le choix d'hommes le plus immoral que j'aye jamais connu », et vantait avec emphase les Canadiens qui auraient formé « une race d'hommes frugals, industrieux et de mœurs... je me glorifie d'avoir été accusé de chaleur et de fermeté en protégeant les sujets canadiens du Roi, et de faire tout ce qui était en mon pouvoir pour gagner à mon maître Royal, l'affection de ce peuple brave et courageux, dont l'émigration si jamais elle arrivait, sera une perte irréparable à cet empire ». Caius tire de ce texte le thème patriotique qui désormais sera repris si souvent en littérature canadienne-française. Murray et ceux qui partagent ses vues, dit-il, sont «DES ANGLAIS! Ce sont là nos VAINQUEURS ! - Ils ne se disaient pas nos conquérants; ils ne nous parlaient pas de conquête, ils auraient voulu la faire oublier ». Pour ce qui était d'《Anglicanus », «Akritomuthos » et autres du parti anglais, dont Murray parlait avec autant de dégoût, Caius concluait: «ceux-là sont vos ancêtres, qui n'étaient venus que pour le butin, qui faisaient sonner ces mots, comme leurs semblables l'ont fait depuis et le font encore $\gg .^{5}$

Ce à quoi «Anglicanus » répliqua avec raison: «The illiberal reflexions of the same writer... on the mercantile body, I know not whether to impute most to malevolence or ignorance. The commercial interest is a monied interest, so interwoven with the state, as to form a component part of it. Their existence and welfare depend on each other $\gg .6$

Le Canadien tente aussi de réfuter les articles d'« Anglicanus » et d' «Akritomuthos » parus dans le Mercury du 24 novembre. ${ }^{7}$ Il cite d'abord des extraits des Débats du Parlement de la Grande-Bretagne à propos de la constitution de 1774 et de celle de 1791, ceux où le législateur exprimait le désir de conserver le Canada à l'Angleterre « par le choix de ses habitants » qui «doivent sentir que leur situation n'est pas moins bonne que celle de leurs voisins $\gg$ :

5 Le Canadien, 29 novembre 1806.

6 Quebec Mercury, 1er décembre 1806.

7 Cf. chap. V. 
Vous voyez bien que loin de suivre les sentiments de ceux dont vous suivez les traces [en tentant d'empêcher les Canadiens d'obtenir les mêmes avantages constitutionnels que vous] l'intention de Sa Majesté exprimée par son premier ministre é celle de son Parlement, a été, en divisant la Province, de donner une Grande Majorité aux Canadiens dans le BasCanada, afin de les soustraire à la tyrannie que vous auriez voulu exercer sur eux.

Vous dites que les Canadiens usent trop librement de leurs privilèges pour des conquis, et vous les menacez de la perte de ces privilèges. Comment osez-vous leur reprocher de jouir des privilèges que le Parlement de la Grande Bretagne leur a accordés ? N'était-ce pas assez d'avoir fait tous vos efforts, d'avoir employé le mensonge et la calomnie, pour empêcher qu'ils ne les obtinssent ?... Ne devriezvous pas vous soumettre enfin à ce que Notre Souverain et son Parlement ont voulu. Quelle différence ont-ils laissé entre vous et les Canadiens; de quel droit osez-vous relever cette distinction odieuse de conquérants et de conquis, quand ils ont voulu l'effacer pour toujours. Vous mettez absurdement en question si les Canadiens ont droit d'exercer ses privilèges dans leur langue; et dans quelle autre langue que la leur peuvent-ils les exercer ? Le Parlement de la Grande Bretagne ignorait-il quel était leur langue ?..... Les Canadiens sont des conquis, mais ce sont des conquis qui vous montreront le chemin de l'honneur; ils ne savent pas être infidèles à leurs Rois et ne sont pas d'une trempe à former des Yenkés. Qu'ont-ils fait pour mériter la menace que vous leur faites de la perte de leurs privilèges ? Estce parce qu'ils vous ont défendu malgré vous en $1775 ?^{8}$

Le ton extrêmement confiant, bien que frisant la bravade, fait voir jusqu'à quel point alors les Canadiens s'en rapportent à l'esprit de justice du parlement britannique. Ils ont pleine confiance en lui. Pour eux, le conflit au Bas-Canada n'est pas encore une querelle de races. Il y a bien leurs ennemis, les « anti-canadiens »; mais il ne faut pas oublier les « bons » Anglais,

${ }^{8}$ Le Canadien, 6 décembre 1806. 
type Murray, «nos amis» qui sont trompés par les premiers, par un homme qui se masque sous les apparences d'un Anglais, tout en empruntant le langage, la doctrine ainsi que la politique d'un citoyen des États-Unis, et qui «emploie plusieurs pages d'un papier public à délayer d'une manière fatiguante pour lui et encore plus pour ses lecteurs cette idée sublime, cette grande théorie qu'il faut défranciser le Canada ». ${ }^{9}$ Il semble que les accusations d'américanisme étaient à la mode et qu'elles s'échangeaient constamment.

Le Canadien ne laisse pas de préciser plus nettement sa distinction entre les premiers marchands de la colonie et ceux de 1805 :

.... Nous admettons par conséquent la différence qu'il doit y avoir entre les premiers Marchands qui suivent l'armée dans un pays conquis, et ceux qui s'y établissent lorsque les choses sont rentrées dans l'ordre, nous étendons même cette conséquence à toutes les autres classes de la société, et nous admettons que la lettre du Général Murray aurait été insérée bien mal à propos dans le Canadien, si elle y eut été insérée pour en faire l'application aux Marchands actuels ou aux autres classes actuelles en général; mais si Nestor veut revoir le no. 2 du Canadien, il trouvera que cette lettre n'est appliquée qu'au parti Anti-Canadien, c'est-à-dire à ceux qui dans l'état actuel des choses que décrit si bien Nestor, montrent encore par rapport aux Canadiens, des sentiments, qu'on aurait dû n'attendre que de gens de l'espèce dont la lettre du Général Murray donne la description. ${ }^{10}$

Destinés, croient-ils, et par la Providence et par le parlement britannique à survivre dans le Bas-Canada, les Canadiens français se refusent à stimuler l'immigration anglaise ou américaine dans la Vallée du St-Laurent, leur patrie. Ils s'y opposeront, combattront de toutes leurs forces, soit à l'Assemblée, soit dans les journaux. «....Qu'apercevons-nous de tous côtés ? Une foule d'étrangers actifs, industrieux, qui jaloux de la bonté du

${ }^{9}$ Le Canadien, 3 janvier 1807.

${ }^{10}$ Le Canadien, 6 décembre 1806. 
sol que nous cultivons, s'en emparent peu à peu, et semblent vouloir nous renfermer dans les bornes les plus étroites. Mais si nous ne prenions les précautions nécessaires, ... ils parviendront peut-être à changer par la suite, notre langage et nos mœurs... Nous formons maintenant, un corps de deux ou trois cent mille individus, et si jusqu'à présent, nous n'avons point encore été entamés... c'est à nos principes religieux et moraux... que nous devons cet avantage ».11 Derniers mots qui sonnent étrangement modernes et pourraient figurer avec avantage en de récents discours «patriotiques».

Prétentions, espoirs assez répandus parmi les Canadiens, mais contre lesquels le Quebec Mercury du 2 février proteste violemment: " It is a singular idea of Le Canadien to treat as strangers all who are not french descendants. As if the offspring, born in the province, of parents who established themselves here in the eighteenth century were not as fully Canadians, as the descendants of those, who settled here in the sixteenth century; and as if the right of the man who comes here in the nineteenth century, were not as strong and valid as that of the man of the sixteenth century, particularly in a country where there is not the least necessity for our elbowing each other, there being abundantly more than room enough for all. If english descendants are strangers, these latter are equally strangers compared with the Huron, Iroquois and other nations, their predecessors. $\gg 12$

Un autre Anglais, qui signe cette fois «Publicus», se porte à la défense des Canadiens français dans le Mercury. Preuve que, malgré son unité, le parti mercantile n'était pas unanime sur les questions de détails :

It was the generous and liberal policy of Great Britain to conciliate the conquered Provincials, by granting them not merely the protection of, but an actual participation in the English laws and constitution ..... What is right and lawful for a British resident in Canada, is also right and lawful for a French Canadian.

11 Le Canadien, 24 janvier 1807.

12 Quebec Mercury, 2 février 1807. 
To suppose that the French could be suppressed altogether in Lower Canada, is highly absurd. It would be even impossible to circumscribe its increase, more than four fifths of the inhabitants speak it exclusively; and admitting that it were possible to suppress it, such an attempt would be an act of tyranny. It would be extremely injust to deprive so great a majority of the people of the information and amusement, which they might derive from a journal written in their own language. ${ }^{13}$

Disons tout de suite, cependant, que le parti anglais, du moins à cette époque, ne se propose nullement d'angliciser de force les Canadiens: "We trust that none of our readers can be misled or deceived by misrepresentations of designing persons, into the belief of there being anywhere a wish or disposition to counteract the french language, as a mother tongue by anything like compulsion. Should there exist such a disposition there can be no power to inforce it. To suppose either one or the other must be the affectation of knavery or the credulity of the grossest ignorance, imposed on by the former, from the worst designs. But to manifest a desire that british subjects, as far as it is practicable, should bear the image and superscription of englishment, is natural and laudable. ${ }^{14}$

Dans le Quebec Mercury du 15 décembre, "Anglicanus» défend sa position contre les allégations de «Publicus». Il ne se prive pas de berner les Canadiens. A l'en croire, ces pauvres gens ne seraient que des vantards incapables de réaliser le progrès de la province:

Two new french periodical papers are proposed, and a new press set up for the purposes of one of them, in this province, at a moment when french power and influence had already surpassed all bounds; when the french minister in the American States, had made a considerable offer towards the establishment of a french paper in New-York; when there were already two gazettes in the province, published as well in the french as in the english language; and

13 Quebec Mercury, 8 décembre 1806.

14 Quebec Mercury, 26 janvier 1807. 
when the english had been forty seven years in the possession of Quebec .....

.... The objection [au français] was to its cultivation as a mother tongue and to its consequent formation of frenchmen, instead of rendering british subjects what they should be, englishmen ...

No man who has in contemplation the real interest of the province, but must look forward, with a degree of satisfaction, to the prospect of its increasing population, by men with english ideas and of industrious habits. It is only to such men, whatever may be the sneers of Le Canadien, we can look for that productive state of the province which can render it an object worth the protection and fostering care of Great-Britain. It would be much more creditable and laudable, if, instead of empty vauntings of loyalty and bravery, the Canadians turned their minds to enumerate their great improvements and the consequent vast products of their labour and industry..$^{15}$

Qu'après quarante-sept ans de conquête, le Canada devrait être d'essence anglaise, antienne qui revient avec une régularité vraiment monotone. Pour «Anglicanus », seuls les Anglais pourront accomplir l'immense développement auquel le Canada est prédestiné.

Dans le même numéro, un autre article, à mots à peine couverts, stigmatise les Canadiens comme des ignorants et des lâches, ou pis, des traîtres :

It is given as an argument in support of a new french paper, that more than four fifths of the inhabitants of Canada speak french exclusively ..... But how many of those four fifths can read ? Perhaps a hundreadth part. Of that hundredth part how many are these whose reading extend beyond the catechism and other small works prescribed by the church ? Perhaps a five hundredth part..... Publish that you will it will reach but a few Canadians. There is such a barrier to their information as the efforts of a dozen presses will not overleap; but on this point I say little. It is a delicate one..... [Pour ce qui

15 Quebec Mercury, 15 décembre 1806. 
concerne la bravoure et la loyauté des Canadiens en cas de danger de guerre avec les Etats-Unis] it seems to be the fashion to compliment the Canadians... I trust I may be permitted to hope that, if ever such danger should stare us in the face, the efforts of the Canadians may be seconded by a few regiments of british regulars; from furnishing which stable defence, I pray heaven that the british government may never be diverted by Canadian professions ..... ${ }^{16}$

Aussi intelligents que leurs compatriotes anglais, les Canadiens ne désirent pourtant qu'un régime vraiment parlementaire et une certaine forme de responsabilité ministérielle. Ils ne peuvent donc priser l'attitude de l'exécutif qui ne manifeste sans cesse de sympathies que pour la minorité de la Chambre et qui souvent se range carrément de son côté. Dans une étude rétrospective sur la querelle des prisons, Le Canadien le note avec une certaine amertume: les membres du Conseil exécutif qui siègent dans la législature, ont fait cause commune avec la minorité: «Ce qu'il y a de singulier dans toutes ces procédures, c'est que le parti ministériel a été constamment du côté des Marchands de Montréal et en opposition avec la Chambre d'Assemblée. Cette circonstance ne semble-t-elle pas montrer combien l'influence de la société du Nord-Ouest, ${ }^{17}$ est dominante dans le pays ..... Ne paraîtrait-il pas que cette influence ne peut avoir que des effets très irréguliers ? Qu'on remarque seulement l'effet que peut avoir dans notre constitution un Ministère constamment dans l'opposition. » ${ }^{18}$ Et encore: «Le ministère doit nécessairement avoir la majorité dans la Chambre des Communes. Dès qu'il perd l'influence qui la lui donne, ou dès que son système ne paraît plus bon, il est relevé ..... La nation exerce son jugement en élisant ceux dont elle approuve le système et la conduite. »19

16 Quebec Mercury, 15 décembre 1806.

17 La Compagnie du Nord-Ouest avait été fondée vers 1784, puis réformée en 1804 sur des bases puissantes. Parmi ses membres les plus influents, on remarquait Richardson, Mure, Sir Alexander McKenzie et B. Frobisher, tous membres de la Chambre d'Assemblée.

18 Le Canadien, 17 janvier 1807.

19 Ibid, 24 janvier 1807. 
Le Canadien revient à la charge dans un numéro subséquent. Sans doute entend-il répondre à ceux qui se sont étonnés d'entendre parler de ministère et de ministres. L'auteur du même article ne manque pas d'exprimer la rancœur des Canadiens contre un exécutif qui ose se lier à la minorité anglaise, et contre le parti anglais qui détient, comme son monopole, toutes les fonctions payantes :

Comme si on pouvait avoir une administration sans ministère, ou qu'on ne put avoir des ministres sans que ce fussent des Pitt ou des Fox. C'est même une maxime de notre ministère qu'il n'y a point de ministère ici et que c'est le Gouverneur qui conduit tout. Cette maxime qui tend à rendre le représentant du roi responsable de tous les conseils des ministres est aussi injuste qu'inconstitutionnelle, en ce qu'elle expose le représentant du roi à perdre la confiance du peuple par les fautes des ministres ..... Ce n'est pas à l'occasion de la taxe des terres seulement que le ministère s'est trouvé dans la minorité; c'est une position où il s'est trouvé si souvent depuis le commencement de notre constitution qu'elle lui est devenue habituelle et qu'il la regarde comme sa position naturelle. Aussi ne sait-on plus ce que c'est que l'opposition; les uns regardent la majorité de la chambre d'assemblée comme le parti de l'opposition et les autres donnent cette fonction au ministère, et c'est peut-être une des raisons qui les empêchent de prendre ouvertement ce titre. Si cet arrangement n'avait point d'autre inconvénient que celui du ridicule, on pourrait s'y faire; mais il en a qui sont d'une nature très sérieuse. Premièrement il tend continuellement à mettre de la mésintelligence entre le représentant du Roi et la chambre d'assemblée. Ce que le parti ministériel n'a pu gagner dans la chambre par ses débats sur la prérogative et les journaux, il essaye de l'emporter auprès du Représentant du Roi ... [qui se fie parfois à] leurs connaissances... Et comme la majorité de la chambre d'assemblée est le côté populaire, il y a dans cet arrangement de choses une tendance à faire paraître le peuple opposé au gouvernement, ce qui est également nuisible aux intérêts du roi et du peuple. Un autre inconvénient qui sort de cet arrangement est celui d'entretenir 
cette odieuse division entre Anglais et Canadiens qui est si nuisible aux intérêts du pays. Car comme tout le ministère est formé d'Anglais, tous les Anglais de la Chambre d'Assemblée se rangent autour d'eux par le préjugé, et la Chambre d'Assemblée se trouve divisée en Anglais d'un côté et Canadiens de l'autre. Comme les premiers se regardent comme la portion privilégiée à laquelle doivent être destinées toutes les places, ils ont l'air d'être plus occupés de se conserver dans cette situation avantageuse que des intérêts des habitants du pays..... On fait donner aux Canadiens quelques petites places pour les tenir dans la dépendance de quelqu'un du ministère et on tâche de choisir ceux qui n'ont aucuns principes et sont incapables d'en avoir..... [Ces derniers] font regarder les Canadiens comme des gens toujours opposés à la prérogative du Roi. Ces idées passent au dehors et cette division entre Anglais et Canadiens devient générale. ${ }^{20}$

«We have lately seen a long dissertation to prove the existence of a Quebec Ministry, in our House of Assembly », réplique mollement le Mercury. «We must doubtless expect shortly to hear of the treasury bench and of the members with the white staves; whose continuation in office is, we suppose, no longer to depend on their commissions, should they be even patrons; but on their securing the votes à la Walpole, of certain bellwethers of our blessed parliamentary flock. ${ }^{21}$ Et c'est la seule réponse du Mercury, d'ordinaire si volubile: il persifle élégamment. Pourquoi ? C'est qu'au fond les Canadiens français ont foncièrement raison. Les Anglais lucides - ils ne sont pas très nombreux surtout dans le Bas-Canada - se rendent compte de l'anomalie qui règne à la législature provinciale. Ceux-là aussi aspirent plus ou moins vaguement à la responsabilité ministérielle. Mais tant que les Canadiens domineront la Chambre, ils s'y opposeront. Pour eux ce serait remettre le pouvoir dans le Bas-Canada, aux vaincus. Il faudra attendre l'Union qui subjuguera les Canadiens et les réduira au rang de minorité. Alors réformistes anglais et réformistes canadiens-français s'allieront

20 Ibid, 31 janvier 1807.

21 Quebec Mercury, 2 février 1807. 
contre les tories des deux parties de la nouvelle province et même contre l'exécutif, toujours récalcitrants contre la métropole ellemême qui n'y comprend pas grand'chose, pour enfin conquérir de haute lutte le gouvernement responsable et l'autonomie intérieure. Le Canadien diagnostique donc parfaitement bien la situation, tant sur la question du parlement tory d'alors que sur celle de l'inégalité dans le partage des fonctions publiques. Il n'atteint pas cependant à la cause profonde, à la racine du mal.

Le 10 mars, le Mercury y va d'un article d'une extrême lucidité. L'auteur, "Nestor», ne cherche pas à fustiger les Canadiens français. Au contraire, il voudrait qu'on les prît plutôt par la douce persuasion. L'intérêt, entend-il leur prouver, leur commande l'anglicisation. La langue anglaise deviendra universelle, prévoit-il, et le Canada connaîtra un immense développement anglais dans les cadres de l'empire. Au Canada même, les Canadiens seront noyés dans une population de langue anglaise:

I think it is greatly to be desired that the english language was universally prevalent in this country .....

Canada is become a part of the british empire, and the more closely it is connected with the body of the empire, the better for both. It is acknowledged universally, that the strength of a whole is increased by the union of the parts. If the junction of the branch to the trunk is defective, if a fracture exists, the nourishment given is checked, the advantages mutually received are weakened... Every barrier to a close connection between Britain and Canada, ought to be removed or avoided, in order to the full enjoyment of all the benefits arising from their connection. I have no doubt myself, that the english language which the Canadians would find the most useful..... Canada must, in time, become a great, populous and mercantile country. There is no country on earth where nature seems to have given such facility to mercantile intercourse, her large lakes, and rivers, open up a vast expense of territory where variety of soil, and climate, will produce every material on which the industry and ingenuity of 
man can operate.... The Canadian ought to recollect that Canada forms a part of America, and that the language of America is english, and ever will be english..... It is the language generally used (much more than the french) by all mercantile men, and seamen ... so that the english language may be said to be at present even, but will, most assuredly in the course of time be the most universal of all language.

L'auteur s'en prend ensuite aux mœurs françaises, si éloignées de celles des anciens Français, ces «gentlemen » qui rendirent leur langue universelle. Les Français d'aujourd'hui sont devenus des meurtriers, coupables de toutes sortes de crimes, « of treasons, treacheries and spoils.....»

There is scarcely a small town in France, where the effects of the revolutionary mania may not be seen ..... It is the fashion at present in France, to behave with all the rudeness of a low-bred grenadier.

[The Canadians] must infalliably be surrounded by people who speak english, with whom it is their destiny to buy and sell, to traffick and to treat... it is evidently the interest of the Canadians to learn English, not to mention how much it is their duty as well as their interest, to learn the language of the head and executive part of their government.

If we take view of the progress of population in Upper and Lower Canada, for these some years past, we will see that the increase of those speaking english has been much greater in proportion to the original stock, than that of those speaking french. This arises from the great influx of people from Europe, and the United States, who bringing with them large families, soon spread over the country ..... The same causes operating will, in course of time, leave the Canadians greatly in the minority. It certainly is surprising that the British government have paid so little attention to the matter. ${ }^{22}$

N'est-ce pas une avant-première d'une partie du Rapport Durham ? «Nestor» nous apparaît un impérialiste très lucide

22 Ibid, 10 mars 1807. 
et très clairvoyant. Il s'illusionne cependant lorsqu'il croit que de simples arguments de raison peuvent endiguer le nationalisme d'un peuple et tuer sa volonté de survivre. Illusion étonnante dans l'état d'esprit des Canadiens qui se targuent - à tort - d'avoir l'appui de Londres. Un autre correspondant du Mercury rappelle le journal à plus de clairvoyance: «Tenacity was the characteristic of the french of all ages..... Were [the priests] educated in Great Britain or Ireland, a regulation that should be legally enforced, and brought up to speak the language and imbibe the ideas of englishmen... the change would be immediate ... A.Z. $\gg^{23}$

Dans cette guerre de plumes issue de la querelle des prisons, les articles cités précédemment nous semblent les plus importants. Le reste de l'année 1807 s'écoule dans un calme relatif et provisoire, présage néanmoins de la tempête qui va bientôt éclater. Cependant, les controverses ne se déroulent pas toujours dans le même air serein. Le Quebec Mercury et le Canadien échangent volontiers épigrammes, poèmes, blagues, etc., où l'ironie et le sarcasme se substituent aux arguments.

Le Mercury choisit comme cible favorite «l'ignorance» des Canadiens. Ainsi, à «Anglo-canadiensis» qui rappelle que les Romains ont adopté l'urbanité des Grecs et qui applique ce fait au Canada, «Anglicanus » rétorque: «The Greeks... the Romans, by this he understands that the urbanity of the Greeks was quickly adopted by the Romans. Unhappy similitude $! \ldots . . \gg^{24}$

Dans la même édition du journal, un autre correspondant qui signe «Sancho», traite tout bonnement les Canadiens de «Dons Quichottes »: «Was I not right in dubbing the Chevaliers of Canadian honor, modern Quixotes ? When they raise a poor squire and others, his terrestial and humble compeers, into Demi gods, must they not possess the perverted imagination of their predecessor, who mistoo, an inoffensive flock of sheep for an armed host ? Sancho. ${ }^{25}$

23 Ibid, 16 mars 1807.

24 Ibid, 24 novembre 1806.

25 Ibid, 24 novembre 1806. 
Que dire de cet «Impromptu»?

Impromptu.

Jean Baptiste thought that he had wit

Till he the trial made,

And found, alas! the duce a bit

Of wit he ever had.

If he is good for any thing,

I'll tell you where it lies:

Give him a Paddle and a Sling,

And he will bear the Price.

Montreal-A YANKEE. ${ }^{26}$

A un correspondant qui déprécie la langue française, le, Mercury fait observer: "We would not have our correspondents hold the french language in no estimation. For talking to children, and making love to the girls, it is admirable $»^{27}$

Le Canadien, quant à lui, ne rate pas une occasion de piquer le parti anglais, il ridiculise de son mieux l'éditeur du Quebec Mercury:

Fable dédiée au Mercure.

L'Erable dit un jour à la ronce rampante:

Aux passants pourquoi t'accrocher ?

Quel profit, pauvre sotte, en comptes-tu tirer ?

Aucun, lui repartit la plante:

Je ne veux que les déchirer. ${ }^{28}$

Parfois, aussi, le ton se montre plus enjoué, plus spirituel:

Chanson

Sur l'air: Robin ture lure lure.

L'apoticaire RACY,

Fait une triste figure

De ne pouvoir plus ici

Lure lure,

Nous vendre de son Mercure

Robin ture lure lure.

Cette drogue bonne à rien,

$\mathrm{Ne}$ peut que nous faire injure,

26 Ibid, 9 février 1807.

27 Ibid, 3 novembre 1806.

${ }^{28}$ Le Canadien, 29 novembre 1806. 
Bon et Sage Canadien, Ture lure, N'a point besoin de Mercure. Robin ture lure.

De fermer ses magasins, Il ferait bien je l'assure, Et d'aller chez nos voisins !

Ture lure

S'ils ont besoin de Mercure.

Robin ture lure.

\section{Epigramme}

L'Effet connu du Mercure, Est douloureux mais puissant, Il répare la nature, Purge la masse du Sang; Mais celui que nous apprête, L'Apoticaire-imprimeur, $\mathrm{Ne}$ fait qu'étourdir la tête

Et nous faire mal au cœur. ${ }^{29}$

Au Mercury qui se lamente sur le sort des marchands, Le Canadien décoche en guise de consolation: "Le Mercure n'a pas besoin d'avoir d'inquiétude, les moutons de Québec ont été braves jusqu'ici, et il peut se fier que les loups de Montréal ne se laisseront pas prendre la laine sur le dos. ${ }^{30}$

Une autre lettre parue dans Le Canadien serait aussi à citer où l'on renvoie aux Anglais l'accusation d'un complot avec les Etats-Unis :

-Mr. Carry,

il sera peut-être trouvé digne de l'attention des philosophes de remarquer combien le vent de NordOuest devient dominant dans ce pays.

C'est à ce qu'on dit la remarque qu'a faite Volney, lorsqu'il est venu ces dernières années faire ses Recherches sur les vents en Amérique.

L'expérience a été faite l'hiver dernier sur un nombre considérable de Girouettes, et a été continuée cet hiver sur sept; et on peut constater par des

29 Ibid, 13 décembre 1806.

30 Ibid, 28 décembre 1806. 
Journaux authentiques, qu'elles ont été constamment dirigées par le Vent de Nord-Ouest, quelque fort qu'ait soufflé le vent d'Est.

Ce vent de Nord-Ouest qui vient des pays froids, et porte droit vers les Etats-Unis, a une influence très maligne sur ce pays; et il pourrait à la fin prendre le dessus sur le vent d'Est même, qui est le vent salutaire au pays. Je crois donc que ce ne serait pas un des moindres exploits des Philosophes, qui ont fait de nos jours tant de belles découvertes, que d'en faire une au moyen de laquelle nous pussions être débarrassés de ce maudis vent de Nord-Ouest, ne sentir que le vent de l'Est.

Les sept Girouettes sur lesquelles l'expérience a été continuée cet hiver sont comme suit: Montréal: 2; William Henri: 1; Québec: 1; Bedford: 1; Gaspé: 1; York: $1 .^{31}$

Ce vent du Nord-Ouest désigne évidemment les marchands de la Compagnie du Nord-Ouest ; 32 ils avaient réussi à introduire plusieurs de ses membres dans la législature provinciale. Par le vent d'Est, entendons l'influence de l'Angleterre. Les «Girouettes» ne peuvent être que les députés anglais à la Chambre législative qui ont tant combattu d'abord la loi des prisons, puis le mémoire de l'Assemblée au roi.

Les journaux ont donc imprimé un essor nouveau à la querelle des prisons. Pour Le Canadien et ses rédacteurs, la querelle n'a pas encore pris le caractère d'un conflit de races, du moins d'une guerre totale. Il s'agit tout au plus de se défendre contre le parti «Anti-Canadiens » ou «Anglais » et d'en appeler aux « bons » Anglais et au gouvernement de Londres. Ce dernier, croient-ils, va leur concéder peu à peu la direction politique du Bas-Canada. Question de temps, se dit-on. Les Anglais et le Mercury cernent de beaucoup plus près et beaucoup plus cyniquement le fond du conflit. Pour eux, deux races et non deux partis se heurtent. L'enjeu est d'éliminer du pouvoir les Canadiens français. Pour cette raison toute simple que le Canada, colonie britannique, doit se développer sous l'impulsion des

31 Ibid, le 22 novembre 1806.

32 Voir la note 1 de ce chapitre. 
Britanniques, dans des cadres britanniques commandés par des Britanniques, non par les conquis.

\section{CONCLUSION}

Un antagonisme profond dressait donc la majorité canadienne-française contre le parti anglais, i.e. les marchands et les fonctionnaires. Ces derniers occupent les plus hauts postes dans l'administration, dominent les Conseils exécutif et législatif, avisent le représentant de la couronne. L'arrivée de Craig et la crise qui va suivre ainsi que le débat sur les juges, transformeront cette opposition violente presqu'en guerre civile. Les esprits sont déjà très montés. Et, pour ce coup, grâce aux journaux, le grand public participera aux débats.

Christie brosse un tableau de la situation qui n'a rien d'exagéré:

The province, by this time, from the agitation that had arisen, was divided into two distinct parties; the one canadian, of french origin, and opprobriously called (for they did not choose to be termed french, an appellative odious in its application to them, and therefore offensive, although the notion of a « la nation canadienne 》 and «nationalité » was not yet in vogue) the french party, consisting principally of the rural and agricultural population; the other british comprising all, or nearly so, of british birth or descent in the province, including the commercial body, without scarcely an exception, each now unhappily animated against the other by blind party spirit, and fierce almost to hostility and the knife, imputing to each other the most iniquitous and absurd views and bandying abuse; the one set characterising their opponents by the odious cant terms of «anti-canadiens, citoyens, or anglais 》 - those of "Frenchmen, democrats, boutefeux, 》 being as freely and indeed angrily bestowed in return by the other class. The apparent origin of these parties is to be found in the conflict previously noticed between the commercial and agricultural interests with respect to the "goals' bills 》, rather than in any prejudices of national origin, which, however, having 
slumbered till then, there is no doubt that this struggle awakened on both sides. ${ }^{33}$

Selon Christie la querelle des prisons aurait allumé la guerre des races. A notre avis, elle ne l'a pas plus suscitée qu'elle n'a créé les deux partis. Ces divergences raciales existaient depuis longtemps, en Amérique, depuis le jour où des Français et des Anglais y avaient mis le pied. Après la conquête, il ne s'écoulera jamais cinq ou six ans sans que ne se produise une ou plusieurs de ces querelles. Comparée aux années 1780 à 1790, la période de 1791 à 1805 semble paisible. Au début du régime de 1791, le manque d'entente entre le pouvoir exécutif et la Chambre d'Assemblée ne s'accuse guère. Dans l'Assemblée elle-même, une fois clos le débat relatif à la langue française, les deux groupes nationaux se tolèrent sans trop de difficultés, s'ils ne font pas tout à fait bon ménage. Sauf quelques désaccords d'importance secondaire, les relations avec le Conseil législatif n'offrent rien de particulièrement tendu. Mais, en 1805, surgit soudain cette querelle des prisons. Tout est remis en question. Apparemment sans importance, cette législation déclencha une crise si aiguë qu'il faut en chercher la cause en dehors de là. Il semble qu'elle ait touché à un point névralgique des relations entre les deux races. De part et d'autre on éprouva force et influence. Froissement qui entraîna aussi la cristallisation hâtive de partis jusque-là mal définis dans leurs cadres, sinon dans leurs idées. A partir de 1805, 1806, 1807, on ne peut plus administrer le pays sans tenir compte de cette lutte entre deux groupes raciaux retranchés dans leurs positions et leurs préjugés.

Depuis 1791, les Canadiens ont le haut du pavé à la Chambre législative. La constitution, monstre d'incompréhension, ne peut que leur laisser espérer une émancipation à plus ou moins longue échéance. Cette émancipation, ils y croient, ils la veulent avec fermeté. Volonté qui s'exprime en leurs pétitions de plus en plus insistantes pour une application plus juste du nouveau régime. Les retards à nettoyer la «clique», nettoyage qu'ils espèrent de la part de Londres, les énervent.

33 Christie, History, 1: 313-314. 
$\mathrm{Au}$ point de vue constitutionnel, les Canadiens ont parfaitement raison, ce qui confère une force singulière à leurs réclamations et embarrasse Londres. Dans son rapport, Durham le reconnaîtra lui-même. Il est normal qu'un peuple veuille devenir nation, qu'une Assemblée cherche à gouverner et que ses membres y obtiennent des postes d'importance.

Les fonctionnaires et certains marchands anglais savent eux aussi qu'un jour viendra où la Chambre législative jouira de la responsabilité ministérielle. Et pour cause: leurs aspirations normales sont les mêmes que les Canadiens. Mais voilà, sous le régime du self-government accordé aux Canadiens, les Anglais, croient-ils, seraient à la merci des vaincus de 1760 , et ceux-ci pourraient bien paralyser l'administration. La crainte de cette dernière hypothèse inspire un mémoire de Ryland à Londres :

-.... Il me semble y avoir aucun moyen existant actuellement (hors l'énergie bien connue et l'habilité du gouverneur en chef) de réagir contre les projets qu'une pareille Chambre d'Assemblée [celle du BasCanada] peut former.

Pour remédier à ce danger, il faudra beaucoup de sagesse jointe à une influence anglaise prépondérante, à la fois dans les conseils législatifs et exécutifs .....

Il est évident pour toute personne au courant de l'état actuel des choses ici, que ni le Banc ni les Conseils tels qu'actuellement composés, ne sauraient être capables de réprimer de la manière voulue toute tentative audacieuse et systématique, de la part de l'Assemblée, d'obtenir une prédominence pernicieuse dans la législature provinciale; encore moins pourrait-on compter que ces corps coopéreraient à l'exécution d'un plan général pour assimiler la colonie à la mère patrie en matière de religion, de lois et coutumes.

L'idée humblement émise que, - préparatoirement aux mesures d'une portée plus particulière - il serait bon d'adjoindre huit ou dix membres au Conseil législatif, dont trois ou quatre seraient des Canadiens du meilleur caractère et des plus respectables 
familles, et le reste des Anglais de la plus forte trempe.....

On propose que les deux plus anciens juges à Québec [Dun et Williams, qui ont tous deux dépassé l'âge de soixante-treize ans] aient l'autorisation de se retirer en touchant une pension; que dans la nomination de leurs successeurs, on veille avec le soin le plus sévère à choisir des hommes capables et fermes, des Anglais que les liens naturels et les coutumes attachent aux lois et à la religion de la mère-patrie .....

Une pareille législation [pour les Cantons, pouvoir de délivrer un writ autorisant l'élection d'un député pour représenter tel canton] non seulement favoriserait la colonisation des terres vaines et attacherait les habitants des cantons au gouvernement de Sa Majesté en leur permettant de participer à l'adoption des lois provinciales, - mais elle constituerait un frein effectif au parti français ou catholique romain qui jouit, en ce moment, d'une prépondérance alarmante.....

Il est vraiment impossible d'attacher trop d'importance à ce sujet ou de le mettre trop en évidence, car il indique la nécessité absolue d'une loi du Parlement impérial si l'on a l'intention d'obtenir jamais quelque chose comme une influence anglaise dans la section inférieure de la Législature provinciale. Car il ne faut pas compter qu'une Chambre d'Assemblée composée comme celle d'aujourd'hui, souffre jamais l'adoption d'un bill relatif à l'encouragement des colons anglais ou encore moins d'un projet qui procurerait à ces colons les moyens d'être représentés dans cette Chambre. ${ }^{34}$

Il faut donc choisir entre les deux; option qui ne peut que favoriser le plus fort. Les Anglais préfèreront attendre, même lutter momentanément contre le self-government tant qu'ils ne

34 «Observations concernant la situation politique du Bas-Canada 》, par Ryland (extraits tirés des Intéressants Documents publics et correspondance officielle, illustrant et complétant l'histoire du Bas-Canada, publié par Robert Christie (Montréal, 1855) et formant le vol. VI de l'Histoire du Bas-Canada de Christie. Une note, insérée par celui-ci, affirme que ce document a été écrit au mois de mai 1808). Cf. A. G. Doughty et D. A. McArthur, ed., Documents constitutionnels, 1791-1818 (Ottawa, imprimeur du roi, 1915), 352. 
pourront l'obtenir pour eux. Ils s'annexeraient aux États-Unis plutôt que d'abandonner le Bas-Canada aux Canadiens. Pourquoi ? Pour toutes ces raisons que Québec et Montréal sont les grands centres commerciaux où convergent et voies de communications et capitaux anglais; parce que le Bas-Canada doit servir de tremplin à toute expansion vers l'Ouest; parce que le Canada, pays immense à peine peuplé, est susceptible de connaître un essor gigantesque grâce à une colonisation que les Canadiens, privés de métropole, ne peuvent entreprendre; enfin, parce qu'il y a eu la Conquête, parce qu'il n'y aura plus de nation canadienne et parce que le peuple maître doit mener le jeu et coloniser.

Deux ennemis armés ne peuvent s'affronter indéfiniment sans en venir aux coups. Rangés en bataille après 1805, les deux groupes raciaux du Bas-Canada entretiendront une lutte continuelle, surtout après 1807 . Le règlement de comptes définitif n'aura lieu qu'en 1837, après des échanges de coups de feu. Dès 1790, mais avec beaucoup plus de lucidité et de coordination après 1820, les Canadiens anglais et les fonctionnaires supérieurs comprirent et affirmèrent que pour solutionner le problème et corriger la situation, il fallait réaliser l'Union. Unir les deux Canadas, c'était éliminer la menace des Canadiens en les réduisant à l'état de minorité, c'était donner la majorité aux Anglais dans la vallée du St-Laurent et ainsi leur permettre d'accéder sans danger au self-government. C'était en même temps renforcir le Canada contre l'influence du trop puissant voisin, les États-Unis. La crise qui débute avec la querelle des prisons, ne se règlera donc qu'avec la sujétion définitive des Canadiens. Dans la suite, ils ne constitueront plus un danger pour le Canada anglais. Tout au plus resteront-ils source d'embarras et d'ennuis administratifs. 